S.Afr. Tydskr. Landbouvoorl./S. Afr. J. Agric. Ext.,

Vol. 44, No. 1, 2016: 25 - 41

DOI: http://dx.doi.org/10.17159/2413-3221/2016/v44n1a374
Khapayi \&

Celliers.

(Copyright)

\title{
FACTORS LIMITING AND PREVENTING EMERGING FARMERS TO PROGRESS TO COMMERCIAL AGRICULTURAL FARMING IN THE KING WILLIAM'S TOWN AREA OF THE EASTERN CAPE PROVINCE, SOUTH AFRICA
}

Khapayi, M. ${ }^{4} \&$ Celliers, P. R. ${ }^{5}$

Corresponding Author: M Khapayi Email: musa.khapayi@nmmu.ac.za

\begin{abstract}
The aim of the study was to investigate the main limiting factors that prevent emerging farmers from progressing from subsistence to commercial agricultural farming in the Eastern Cape Province. The study was conducted in the King William's Town area by means of a structured questionnaire survey. A sample of 50 households was drawn from the research area which was chosen owing to its uniqueness with regard to agricultural potential. A descriptive analysis technique was employed to investigate the main limiting factors faced by farming households in migrating towards commercial agricultural markets. The findings demonstrated that the specific limiting factors emerging farmers face are poor physical infrastructure such as poor roads, lack of transportation to the markets from the farms, lack of marketing skills and information, poor market infrastructure, and high transaction costs, insufficient land availability to expand production, lack of agricultural implements to better production, poor production and farm management skills, as well as low education levels which results in an inability to interpret market information to be used in production planning and marketing. The results from the study highlighted that the government has a crucial role to play in increasing market participation of emerging farmers through encouraging group marketing, upgrading of roads to enable smooth accessibility of farmers to output markets and the establishment of local point sales in farming rural areas. Finally the study recommended that government provides planned workshops to all farmers in order to equip them with marketing knowledge.
\end{abstract}

Keywords: Emerging farmer; Constraints; Eastern Cape Province.

\section{INTRODUCTION}

A number of studies have been conducted on the topic of commercialisation of emerging farmers with the aim of broadening the knowledge on the challenges that limit such migration from subsistence to commercial farming. Despite the valuable knowledge generated by these studies, there is still a remarkable scarcity of scientific information describing a more detailed picture of major challenges that affect emerging farmers. The South African government has in the past 18 years implemented several policies and programmes as well as increased the budget spent on the agricultural sector supporting emerging farmers (Department of Agriculture Forestry and Fisheries, 2010; Frequin, Anseeuw \& Da'Haese, 2012; National Treasury, 1996, 2004, 2005, 2008, 2010 and Aliber \& Hall, 2012). However to-date there is inadequate evidence that these attempts had been successful (Frequin, Anseeuw \& Da'haese, 2012; National Treasury, 1996, 2004, 2005, 2008, 2010; Aliber \& Hall, 2012).

\footnotetext{
${ }^{4} \mathrm{PhD}$ candidate, Department of Agriculture and Game Management, Nelson Mandela Metropolitan University, Port Elizabeth, South Africa. E-mail: musa.khapayi@nmmu.ac.za.

${ }^{5}$ Senior lecturer, Department of Agriculture and Game Management, Nelson Mandela Metropolitan University, Port Elizabeth, South Africa Email:Phillip.Celliers2@nmmu.ac.za.
} 
S.Afr. Tydskr. Landbouvoorl./S. Afr. J. Agric. Ext.,

Vol. 44, No. 1, 2016: 25 - 41

DOI: http://dx.doi.org/10.17159/2413-3221/2016/v44n1a374
Khapayi \&

Celliers.

(Copyright)

Indeed programmes and other attempts by government and development agencies have exacerbated rather than alleviated the difficulties emerging farmers face (Frequin et al, 2012). To-date emerging farmers still living below the poverty line are faced with difficulties in migrating into the commercial agricultural sector (Frequin, et.al 2012; Aliber \& Hall, 2012). The failure of several attempts by government to integrate emerging farmers into the commercial agricultural economy has increased the need for a well-grounded scientific knowledge and a thorough understanding of these challenges that emerging farmers' face.

A better understanding of specific factors that limit the development of emerging farmers is crucial in order to effectively prepare policies, development strategies, programmes and models aimed at supporting and enhancing the transition of emerging farmers into commercial agricultural farming. South Africa can no longer afford to run the risk of development programmes and policy intervention aimed at emerging farmers that do not work seemingly not because they are not working but because the challenges emerging farmers face were not correctly identified. Given the prominence of the topic the main objective of this article is to provide a scientific understanding of the challenges, issues and barriers emerging farmers face at transitioning into commercial farming as well as provide the relationship limiting factors have with the commercialisation of emerging farmers. Commercialisation of emerging farmers is a crucial topic for the current times in South Africa. The present study is primarily focused on the factors that limit the transition of emerging farmers in the King William's Town area from successfully participating in commercially viable markets. In the study it is assumed that commercialisation of subsistence agriculture implies increased participation in remunerative agricultural commercial output markets.

\subsection{Issues and challenges for emerging farmers in South Africa}

The South African agricultural economy has little room for emerging farmers. There is no strong support system available to support previously disadvantaged farmers (Chikazunga \& Paradza, 2012:3-4), causing such farmers to be unable to take advantage of the various opportunities that the South African government has been instituting (Moloi, 2010:46 \& Anyike, 2011). According to a study by Chikazunga \& Paradza (2012:4), South African agricultural economy grew rapidly under the previous South African government owing to strong state subsidies and support programmes aimed at supporting commercial farmers. Similar support programmes and state subsidies were seen as encouraging the agricultural economy of the United States of America and Europe (Chikazunga et.al, 2012:4). Currently South African agriculture depends heavily on world markets for marketing agricultural products (Chikazunga et al. 2012:3-4). The removal of marketing boards' state subsidies along with the de-regulation of the agricultural sector subsequent to the democratic transition in 1994 caused serious problems for commercial farmers in particular to previously disadvantaged farmers. By 1997 interest rate subsidies and export subsidies had ended completely and by late 1998 all marketing control boards were privatised with only the sugar industry continuing to have price support from the government (Chikazunga et al. 2012:3-4). Many emerging farmers face difficulties in accessing formal agricultural markets. As a result formal markets do not interest emerging farmers. Lack of market participation is a common feature of emerging farmers world-wide and is identified by Bie'nabe \& Vermuelen (2011:494) as a constraint to emergent farmer development. In South African underdeveloped rural areas emerging farmers find it difficult to participate in commercial markets because of a range of constraints (Makura \& Mokoena 2001:455; Wynne \& Lyne, 2003:566). Attempts by farmers to market their commodity are mostly affected by poor infrastructure, 
S.Afr. Tydskr. Landbouvoorl./S. Afr. J. Agric. Ext.,

Vol. 44, No. 1, 2016: $25-41$

DOI: http://dx.doi.org/10.17159/2413-3221/2016/v44n1a374
Khapayi \&

Celliers.

(Copyright)

inadequate property rights (Wynne \& Lyne, 2003:566; Wynne \& Lyne, 2004:9), low education levels amongst the farmers, lack of credit access, absence of innovative production implements needed in-order to increase yield of commodity produced and poor entrepreneurial skills needed to make the efforts of the farmers a success (Bie'nabe \& Vermuelen, 2011:494). Research conducted by the National Emergent Red Meat Producer's Organisation (2004) identified a number of skills shortages among emerging farmers such as a major constraint of growth. NERPO (2004) suggested that the new South African government must improve its efforts in attracting young people into the agricultural industry. Poor financial and social capital and limited access to legal resources make it difficult for emerging farmers to change negative market factors individually. As a result emerging farmers continue to be trapped in a cycle of operating within the given market from which their agricultural activities do not receive rewards (Makhura et al. 2001:456).

\section{METHODOLOGY}

It has been noted in the literature that some researchers use the term methods and methodology interchangeable (Hussey \& Hussey, 1997:35). Many researchers consider methodology as an overall study approach that is undertaken and methods as various means by which data is collected and analysed. According to Mason (2002:30) the concept of methodology is separated from method. A method is part of the methodological strategy (Mason, 2003:30). Saunders, Fernandes \& Kosnes (2009:3) explain methodology as the theory of how a research study should be undertaken and that it entails the study design and the methods that are used for data collection and analysis.

The approach taken in this study is to include all aspects of the research process under the heading of methodology. Therefore the research design, the approach taken in this study, the type of data collection methods selected and the means of data analysis are all considered to be part of the study's methodology.

To ensure that the survey will get to the heart of the research problem and enable the researcher to answer the research questions a pilot study was conducted in Port Elizabeth, Rocklands and Uitenhange. The pilot study was also conducted to pre-test the questionnaires used for the present study data collection. The main survey to obtain the primary data for this study was conducted in King William's Town an area situated in the central region of the Eastern Cape Province. Agriculture in this area is the most used enterprise for household survival followed by operating shebbeens and taverns and the State grant (Moloi, 2010:47). Most inhabitants in the identified area relied on farming for household survival. Data was collected using structured questionnaires. A survey of households provided much needed information on the demographics of the group of farmers such as their socio-economic characteristics. The survey involved 50 households selected in the research area.

In selecting a suitable representative sample the researcher followed a two-stage sampling process, in which the first stage involved selecting the survey area. This was followed by selecting the total number of emerging farmers engaged in agriculture in the area. It was found that the total number of agricultural households in the area is 43624 (Statistics South Africa \& Department of Agriculture, 2000; Statistics South Africa, 2010; Statistics South Africa, 2011). This consisted of mainly commercial farmers (Statistics South Africa \& Department of Agriculture, 2000; Statistics South Africa, 2010; Statistics South Africa, 2011). According to Statistics South Africa (2011), the country lacks information on smallholder and subsistence agriculture. The current list of farmers being used to conduct 
S.Afr. Tydskr. Landbouvoorl./S. Afr. J. Agric. Ext.,

Vol. 44, No. 1, 2016: 25 - 41

DOI: http://dx.doi.org/10.17159/2413-3221/2016/v44n1a374
Khapayi \&

Celliers.

(Copyright)

surveys is mainly confined to commercial agriculture. Until now agricultural censuses and surveys have largely concentrated on commercial agriculture and have ignored small-scale and subsistence agriculture (Statistics South Africa, 2010; 2011). Thus a total number of subsistence farmers in the survey area could not be realized from Statistics South Africa or the Department of Agriculture.

The researcher established that emerging farmers in the area had formed associations as farmers. A list of emerging farmers' associations and the members of the associations was obtained from a non-government organization (NGO) aimed at assisting emerging farmers in the area. The researcher approached the chairman of the NGO and explained the objectives and the purpose of the study. No objections were made by the chairman. The researcher attempted to interview all the farmers on the list totalling to 124 , but many farmers declined to participate in the study for a variety reason; some farmers were farming for household consumption where only surplus was marketed; some farmers were involved in other businesses, thus farming part-time; and some farmers were inactive owing to various constraints. These farmers could not participate in the study. The target group of the study was on emerging farmers that depend on the farm sources for household survival, farming full-time and producing mainly for the market. The researcher applied criteria of availability, willingness to cooperate and a sampling size of 50 was realised amongst those farmers available and willing to participate.

In general researchers prefer probabilistic or random sampling methods over nonprobabilistic ones. They consider the former to be more accurate and rigorous. However, in applied social research there are circumstances where it is not feasible, practical or theoretically sensible to apply a random sampling method (Trochim, 2006a: 361). A nonprobabilistic method was used in the present study. According to Trochim (2006b:10) purposive sampling is one of the methods of non-probability sampling. It is approached with a specific plan in mind and targets a specific sample. The sampling procedure is further subcategorised as snowballing. In snowball sampling the researcher identifies the participants that meet the criteria for inclusion, and the participants are then asked to recommend others who they may know, who also meet the criteria for inclusion in the study. Although this method would hardly lead to representative samples, there are times when it may be the best method available (Trochim, 2006:10). In the case of the present study, farmers had formed associations as mentioned earlier, which made it easy for participants to recommend others as they knew each other well.

A questionnaire was used to collect data. According to Truckman (2000) and Van Niekerk (2002:35), questionnaire survey methods make it possible to measure what a person knows and the type of information he/she has, the values and beliefs of the person and the attitudes towards what the questionnaire is about. When conducting a questionnaire survey it is better to use an administered questionnaire for better results (Van Niekerk, 2002:36). The questionnaire survey can be used in three different ways namely: personal interviews, telephonic interviews and mail interviews (Randela, 2005:9). The present study made use of personal interviews because they enable the interviewer to observe behaviour that the questionnaire is not designed to detect. The questionnaire was relevant to the objectives of the study and the respondents involved in the study.

The questionnaire consisted of section A and section B. Section A contained questions on demographic characteristics and socioeconomic factors. While section B contained questions covering farming skills of the respondents and production and marketing challenges the 
S.Afr. Tydskr. Landbouvoorl./S. Afr. J. Agric. Ext.,

Vol. 44, No. 1, 2016: 25 - 41

DOI: http://dx.doi.org/10.17159/2413-3221/2016/v44n1a374
Khapayi \&

Celliers.

(Copyright)

respondents face. The questions in the questionnaire were designed in English but during the interviews they were translated in isiXhosa by the researcher, the language of the survey area and understood by the participants. The researcher understands that most of emerging farmers have low education levels and people express their views better when they express them in their own language. The respondents were asked to select the challenges that affect them the most from all the common challenges that were listed in the questionnaire. All data collected were based on the main factors affecting the migration of emerging farmers into commercial markets in the survey area.

\subsection{Data analysis}

The data collected from the questionnaire in this study was coded by the researcher by assigning a numerical value in order to facilitate easier workability on the SPSSx program version 21 and Statistical version 11. The Microsoft Office Excel 2010 software package was used to capture the coded data. This made it easier for the researcher to check for mistakes before analysing the data in SPSSx and Statistical. The Institute for Statistical Consultation at the Nelson Mandela Metropolitan University carried out the processing of the data, using the statistical Package for Social Science and Statistical, software used for statistical analyses. The percentages calculated were based on the total number of farmers who responded to that particular question. The farmers that did not respond to a particular question were excluded from the calculation of percentage values for that question. When a farmer selected more than one answer or gave more than one method to a question, percentages were calculated for each group of similar answers.

\section{RESULTS AND DISCUSSIONS}

The information that follows result from a descriptive analysis of the data collected. The results are presented using descriptive statistics frequencies, counts, charts, percentages and standard deviations. All respondents were interviewed on their farms by appointment. Interviewing the respondents in their farms permitted the researcher to observe their farming areas. The respondents were asked to motivate their answers to verify whether they understood what they were being asked. In this regard all the results in the present study are assumed to be correct and valid.

The study used data collected from a sample of 50 emerging farmers using a questionnaire survey. All 50 farmers were engaged in livestock rearing; about 30 of whom were also engaged in crop production.

Figure 1 below shows the distribution of the farmers by their level of education. The education levels of the farmers were low. Figure 1 shows that $12 \%$ of farmers had less than grade 8 school level; $32 \%$ had grade $8 ; 18 \%$ had grade $9 ; 16 \%$ had grade $10 ; 18 \%$ had grade 11 ; and $4 \%$ had completed grade 12 . This means that $62 \%$ of the farmers had less than a grade 10 school level. None of the heads of households had tertiary education. 
S.Afr. Tydskr. Landbouvoorl./S. Afr. J. Agric. Ext.,

Khapayi \&

Vol. 44, No. 1, 2016: 25 - 41

Celliers.

DOI: http://dx.doi.org/10.17159/2413-3221/2016/v44n1a374

(Copyright)

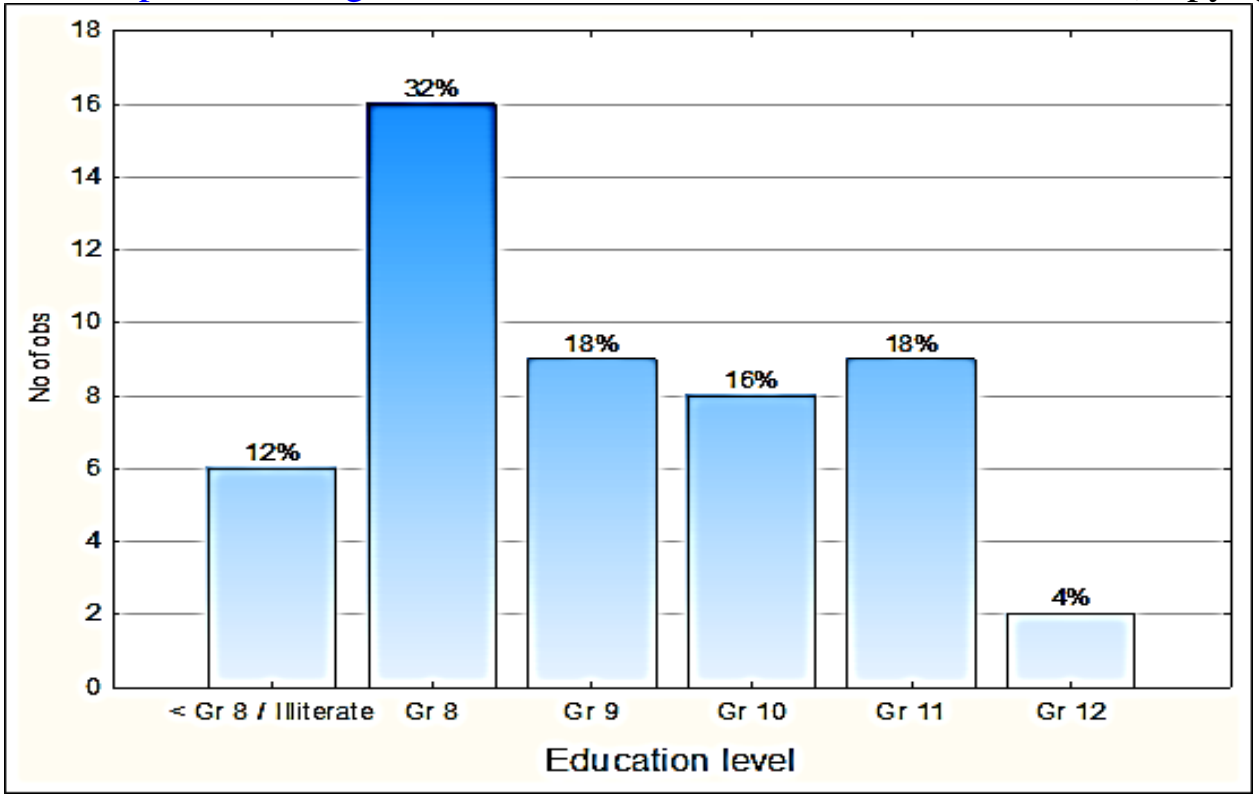

Figure 1: Distribution of farmers by education level

\subsection{Farming skills}

Twenty-six items were used to measure the level of adequacy of the farmers on farming and management skills necessary to operate crop and livestock production farms. The farmers were measured according to their line of production. Farmers solely engaged in livestock production were asked to respond to livestock production questions and management questions in the questionnaire only. The farmers that were also engaged in crop production were asked to respond to the livestock and crop production questions since they were also engaged in livestock production as well as the management questions. The questions were designed using four point Likert scale. Likert scale is a psychometric scale commonly used in researches which employs questionnaire as a survey instrument. After the questionnaires were completed each item was analysed and presented separately. In this study experience is equal to knowledge. It is assumed that if a farmer has knowledge of a certain aspect it will be easier to find experience along the way. Similarly if a farmer has experience about certain aspects then the farmer will have knowledge on that experience.

\subsection{Crop production skills}

Twelve items were used to measure the level of adequacy of the respondents on crop production skills necessary to operate a crop production enterprise. The results are shown on Table 1. For most of the items the farmers perceived their level of adequacy to be inadequate or they did not know. The farmers said that all the skills listed were important for them to know as farmers and knowing them would contribute towards their development to commercial farming and accessing lucrative markets. The farmers further claimed that given an opportunity to learn the skills they would learn them. Limited knowledge as well as lack of skills in crop production among farmers constrains crop production, particularly in small scale irrigation systems. The following table shows the distribution of the sampled farmers experience on skills need for successful crop production. 
S.Afr. Tydskr. Landbouvoorl./S. Afr. J. Agric. Ext.,

Vol. 44, No. 1, 2016: 25 - 41

DOI: http://dx.doi.org/10.17159/2413-3221/2016/v44n1a374
Khapayi \&

Celliers.

(Copyright)

Table 1: Distribution of farmers experience on crop production skills

\begin{tabular}{|l|l|l|l|l|}
\hline \multirow{2}{*}{ Farming skills (N=30) } & \multicolumn{4}{|l|}{ Level of adequacy \% } \\
\cline { 2 - 5 } & Don't know & Inadequate & Adequate & Outstanding \\
\hline Mulching skill & $57 \%$ & $33 \%$ & $7 \%$ & $3 \%$ \\
\hline Seed bed and care skill & --- & $47 \%$ & $50 \%$ & $3 \%$ \\
\hline Soil preparation skill & $33 \%$ & $13 \%$ & $50 \%$ & $3 \%$ \\
\hline Tillage skill & $83 \%$ & $17 \%$ & --- & --- \\
\hline Transplant skill & $30 \%$ & $36 \%$ & $27 \%$ & $7 \%$ \\
\hline Irrigation skill & $57 \%$ & $43 \%$ & - & --- \\
\hline Pest control skill & $90 \%$ & $10 \%$ & - & --- \\
\hline Weed control skill & $20 \%$ & $57 \%$ & $23 \%$ & --- \\
\hline Knowledge of fertilizers & $17 \%$ & $37 \%$ & $47 \%$ & - \\
\hline Harvesting planning skill & $37 \%$ & $37 \%$ & $27 \%$ & - \\
\hline Packing skill & $63 \%$ & $30 \%$ & $7 \%$ & - \\
\hline Grading skill & $83 \%$ & $13 \%$ & $3 \%$ & - \\
\hline
\end{tabular}

As depicted in Table 1, majority of the sampled farmers namely $57 \%$ had no experience in mulching and $33 \%$ had inadequate experience. The farmers did not practise mulching on their farms owing to insufficient knowledge about mulching and its application. Only $7 \%$ had adequate experience and $3 \%$ had an outstanding experience.

For seed bed and care skills $47 \%$ of the farmers had inadequate experience and $50 \%$ had adequate experience. The farmers with inadequate experience in seed bed and care skills were buying their seedlings from commercial farmers and nurseries. Only $3 \%$ of the farmers had an outstanding experience in producing their own seedlings.

A total of $57 \%$ of the farmers were not irrigating their farms, $43 \%$ had inadequate knowledge about irrigation equipment and were also not irrigating in their farms owing to lack of irrigation equipment. The farmers claimed that the irrigation equipment is expensive to buy and could not afford to buy it. The majority of the farmers were using hosepipes and watering cans to water their crops.

Pests can cause mechanical damage to the produce affecting yield quality and resulting to yield loss. Weeds compete with crops for nutrients and can habour pests with a negative effect on the planted crop. The sampled farmers had no integrated pest or weed management measures in place to control pests and weeds. When asked about the use of chemical pesticides, the farmers claimed that they were afraid of using pesticides owing to lack of understanding on the use of chemical pesticides.

A correct application of fertilizer on crops normally boosts production and the possibility of the farmer to be engaged in high value markets. The majority of the farmers namely $17 \%$ had no experience of using fertilisers, $37 \%$ had inadequate experience and $47 \%$ had adequate experience. The farmers revealed that they cannot afford to buy chemical fertilisers owing to high prices. 
S.Afr. Tydskr. Landbouvoorl./S. Afr. J. Agric. Ext.,

Vol. 44, No. 1, 2016: 25 - 41

DOI: http://dx.doi.org/10.17159/2413-3221/2016/v44n1a374
Khapayi \&

Celliers.

(Copyright)

Harvesting is the final stage of the production cycle where the invested capital yields income to pay debts and to buy production inputs. If harvesting is not well planned and managed the capital invested will not yield the profit needed to buy production inputs. The sampled farmers claimed that they do not plan prior the harvesting period. They did not even know that they had to plan for harvesting.

Poor packing of produce can cause mechanical damage. Mechanical damage causes rotting of produce, resulting in poor yield quality. The majority of consumers look at the appearance of produce before buying it (Raleting, 2011:68). The majority of the farmers were packing their produce in available plastic bags during the harvesting time.

\subsection{Livestock rearing skills}

Seven items were used to measure the farmers' level of experience in livestock skills necessary to operate a livestock enterprise. The results are shown in Table 2. For most of the items farmers perceived their level of experience to be either no experience or inadequate experience. Calf rearing is an important activity on a livestock farm because young calves are the future of the herd. Well reared healthy calves produce high yielding healthy adults. The majority of the sampled respondents namely $44 \%$ had no experience in calf rearing and $52 \%$ had inadequate experience in calf rearing while $2 \%$ had adequate experience in calf rearing. The majority of the farmers $48 \%$ claimed not to plan for the weaning of their calves, $46 \%$ had adequate experience in calf weaning and $6 \%$ had outstanding experience in calf weaning and claimed to plan for weaning of their calves as well as to keep records of everything such as the mother of the calf and the father.

The majority of sampled households were not able to identify sick animals, diagnose them or solve the health problem prior to it becoming a severe condition. The respondents relied mostly on other neighbouring farmers and animal technicians that rarely visit the farms. However they were able to recognise animals with foot-rot and mastitis. The hygiene of livestock and the farm helps to prevent disease build up and outbreaks among livestock. Calf pneumonia can be minimised by cleaning the houses where calves are kept. Hygienic feeding equipment helps to prevent the transmission of disease. Trimming and cleaning hooves of livestock help to prevent foot rot disease among livestock. The majority of the farmers $(98 \%)$ claimed not to be informed about animal and farm hygiene and as a result it was not a concern of theirs. The majority of farmers had no systematic breeding programme or approach they were following for breeding their livestock. The farmers had no experience or inadequate experience of breeding skill. With artificial insemination skill farmers can breed their own desired breeds. This is a cheaper method than buying breeds from certified breeders. A total of $88 \%$ of the farmers claimed not to have experience on artificial insemination skill; $8 \%$ perceived their level of experience on artificial insemination skill to be inadequate and $4 \%$ of the farmers perceive their level of experience in artificial insemination skills to be adequate. The following table shows the distribution of the farmer's experience on skills necessary for livestock production. 
S.Afr. Tydskr. Landbouvoorl./S. Afr. J. Agric. Ext.,

Vol. 44, No. 1, 2016: 25 - 41

DOI: http://dx.doi.org/10.17159/2413-3221/2016/v44n1a374
Khapayi \&

Celliers.

(Copyright)

Table 2: Distribution of farmers experience on livestock farming skills

\begin{tabular}{|l|l|l|l|l|}
\hline \multirow{2}{*}{ Farming skills (n=50) } & \multicolumn{4}{|l|}{ Level of adequacy \% } \\
\cline { 2 - 5 } & Don't know & Inadequate & Adequate & Outstanding \\
\hline Calf rearing skill & $44 \%$ & $52 \%$ & $2 \%$ & $2 \%$ \\
\hline Weaning skill & $48 \%$ & -- & $46 \%$ & $6 \%$ \\
\hline Animal health skill & $2 \%$ & $46 \%$ & $46 \%$ & $6 \%$ \\
\hline Animal hygiene & $42 \%$ & $52 \%$ & $6 \%$ & - \\
\hline Livestock breeding skill & $14 \%$ & $60 \%$ & $24 \%$ & $2 \%$ \\
\hline Artificial insemination skill & $88 \%$ & $8 \%$ & $4 \%$ & - \\
\hline Animal nutrition skill & $10 \%$ & $20 \%$ & $62 \%$ & $8 \%$ \\
\hline
\end{tabular}

\subsection{Management skills}

Seven items were used to measure the level of adequacy of the sampled farmers in different farming management skills necessary to operate a livestock or crop production farm. The frequencies for these items are shown in Table 3. For most of the items the farmers perceived their experience to be inadequate or adequate. However, there were some farmers with no knowledge in certain management skills although some farmers had outstanding experience in certain management skills. The farmers agreed that skills such as business management, marketing skills, banking skills, labour management and record keeping are critical for successful farming and knowing them could contribute towards the success of their farms.

Educating small scale farmers on management skills need to compliment the policies which are geared towards small scale farmers' development. Agribusiness requires some knowledge of how the commodity has been produced, the amount and brand of fertiliser and the chemicals applied. All these are achievable through good management skills.

Table 3: Distribution of farmers by experience on management skills

\begin{tabular}{|l|l|l|l|l|}
\hline \multirow{2}{*}{ Management skills (n)=50 } & \multicolumn{4}{|l|}{ Level of adequacy \% } \\
\cline { 2 - 5 } & Don't know & adequate & inadequate & outstanding \\
\hline Labour management skill & $8 \%$ & $66 \%$ & $20 \%$ & $6 \%$ \\
\hline Equipment maintenance skill & $12 \%$ & $38 \%$ & $38 \%$ & $12 \%$ \\
\hline Banking skill & $10 \%$ & $66 \%$ & $18 \%$ & $6 \%$ \\
\hline Entrepreneurial skill & $20 \%$ & $68 \%$ & $8 \%$ & $4 \%$ \\
\hline $\begin{array}{l}\text { Bookkeeping or recordkeeping } \\
\text { (financial management) }\end{array}$ & $10 \%$ & $56 \%$ & $22 \%$ & $12 \%$ \\
\hline Marketing skill & $10 \%$ & $74 \%$ & $14 \%$ & $2 \%$ \\
\hline Farm planning skill & $52 \%$ & $40 \%$ & $6 \%$ & $2 \%$ \\
\hline
\end{tabular}


S.Afr. Tydskr. Landbouvoorl./S. Afr. J. Agric. Ext.,

Vol. 44, No. 1, 2016: 25 - 41

DOI: http://dx.doi.org/10.17159/2413-3221/2016/v44n1a374
Khapayi \&

Celliers.

(Copyright)

\subsection{Marketing challenges}

Seven items were used to identify the marketing challenges faced by the farmers. The frequencies for the items are shown in Table 4. The findings showed that the sampled farmers are faced with marketing challenges such as insufficient market facilities, scale pens and loading ramps for livestock farmers, insufficient market information, low prices, cheap food imports coming from other countries and high transaction costs. Even farmers who managed to produce products of good quality were not realising good profits from their produce owing to insufficient markets being available. The harvests of the farmers were lost after harvesting because of spoilage. Many of the farmers tried to sell their produce to big supermarkets but were told that their produce does not meet the requirements specified by the supermarkets and lack certificate for Good Agricultural Practises. The following table shows the distribution of marketing challenges that mostly affect the sampled farmers.

Table 4: Marketing challenges faced by farmers

\begin{tabular}{|l|l|l|}
\hline Description $\quad(\mathrm{n}=50)$ & $\begin{array}{l}\text { Challenging } \\
\text { factor }\end{array}$ & $\begin{array}{l}\text { Not } \\
\text { challenging } \\
\text { factor }\end{array}$ \\
\hline $\begin{array}{l}\text { Insufficient marketing facilities, such as sale pens and } \\
\text { loading ramps }\end{array}$ & $100 \%$ & - \\
\hline Long distance from farms to markets & $100 \%$ & ---- \\
\hline Insufficient market information & $100 \%$ & ---- \\
\hline $\begin{array}{l}\text { Physical infrastructure such as poor roads to markets and } \\
\text { lack of storage facilities }\end{array}$ & $100 \%$ & - \\
\hline $\begin{array}{l}\text { Changes in the markets such as price changes in relation } \\
\text { to supply and demand }\end{array}$ & $92 \%$ & $8 \%$ \\
\hline Transaction costs & $94 \%$ & $6 \%$ \\
\hline Cheap food imports from other countries & $98 \%$ & $2 \%$ \\
\hline
\end{tabular}

\subsection{Transportation costs}

Amongst the marketing challenges the farmers face were high transportation costs. Marketing transport is important as it links the farmers to the markets or consumers on time. The availability of one's own market transport influences the delivery time of produce to the markets, unlike the case of farmers who depend on hired transport or public transport to transport their produce. Transport availability determines the quality of the delivered produce. Unreliable transport can lead to the late delivery of produce. In the case of emerging farmers who lack storage facilities late delivery of produce can result in loss of produce quality and rendering the producer unreliable to the buyer. Table 5 shows the transportation cost of emerging farmers per year. The majority of the farmers were spending between $\mathrm{R}$ 3000 to above R 5000 on transportation per annum.

Farmers that are close to the road and have access to transport are better integrated to the markets as compared to farmers that are not. The majority of the farmers' localities were situated far from public roads and were serviced by gravel roads which were not well maintained and impenetrable during rainy conditions. 
S.Afr. Tydskr. Landbouvoorl./S. Afr. J. Agric. Ext.,

Vol. 44, No. 1, 2016: $25-41$

DOI: http://dx.doi.org/10.17159/2413-3221/2016/v44n1a374

Table 5: Costs of transportation per annum

\begin{tabular}{|l|c|c|}
\hline Costs & Count & Percentage \\
\hline R0 - R1000 & 1 & 2.00 \\
\hline R1001 - R2000 & 1 & 2.00 \\
\hline R2001 - R3000 & 5 & 10.00 \\
\hline R3001 - R4000 & 13 & 26.00 \\
\hline R4001 - R5000 & 8 & 16.00 \\
\hline Above R5000 & 22 & 44.00 \\
\hline
\end{tabular}

Khapayi \&

Celliers.

(Copyright)

\subsection{Marketing channels}

Emerging farmers use different types of marketing channels to market their produce. Each marketing channel has associated costs such as transportation costs, profits and prices of produce. Before choosing a marketing channel a farmer has to consider these costs. The farmers' choice of marketing channel can pose problems and result in lower earnings. In general, the income of the farmer can be determined by the choice of marketing channel used. The farmers claimed to be using more than one marketing channel: in that case they were allowed to choose more than one answer from the questionnaire. The results were treated separately and are presented separately in Figure 2. Therefore the percentages in Figure 2 are expected not to add up to $100 \%$ as one answer was chosen more than once from the questionnaire. The majority of the sampled farmers appeared to be using informal markets to market their commodity, such as neighbours, rural consumers, farm gates, local traders and urban spot markets. The following figure shows the distribution of marketing channels used by the farmers.

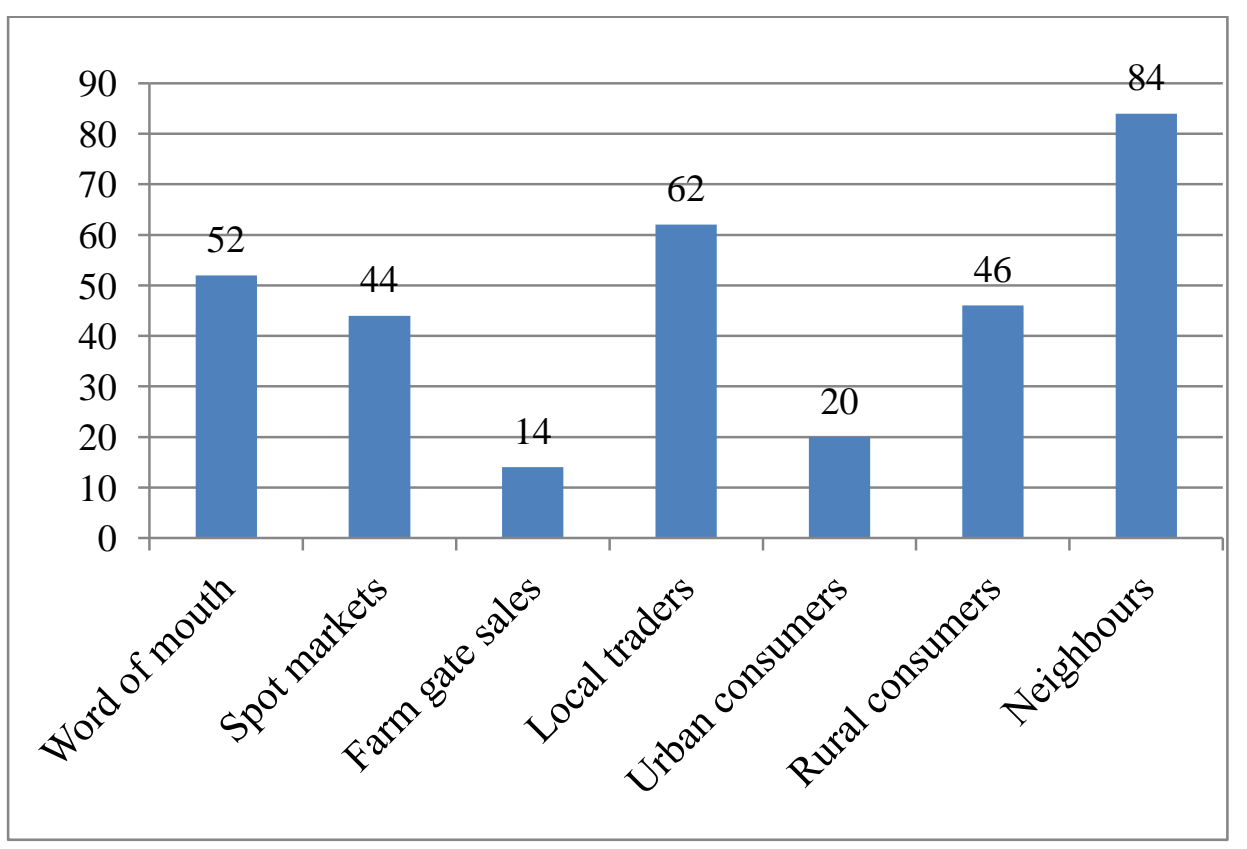

Figure 2: Distribution of marketing channels used by farmers 
S.Afr. Tydskr. Landbouvoorl./S. Afr. J. Agric. Ext.,

Vol. 44, No. 1, 2016: 25 - 41

DOI: http://dx.doi.org/10.17159/2413-3221/2016/v44n1a374
Khapayi \&

Celliers.

(Copyright)

\subsection{Poor access to market information}

As shown in figure 3 the majority of the sampled farmers $(55 \%)$ did not have access to market information. Such farmers are unlikely to participate in marketing because they are not well informed of what is happening in the markets. The farmers were not well informed of market prices, products in supply or the products in demand. Only $45 \%$ of the farmers had access to market information. The majority of the farmers with access to market information relied on family members, self-research and other farmers for market information. The farmers claimed that the information was not timely, was sometimes biased and was unreliable making the usefulness of the information doubtful.

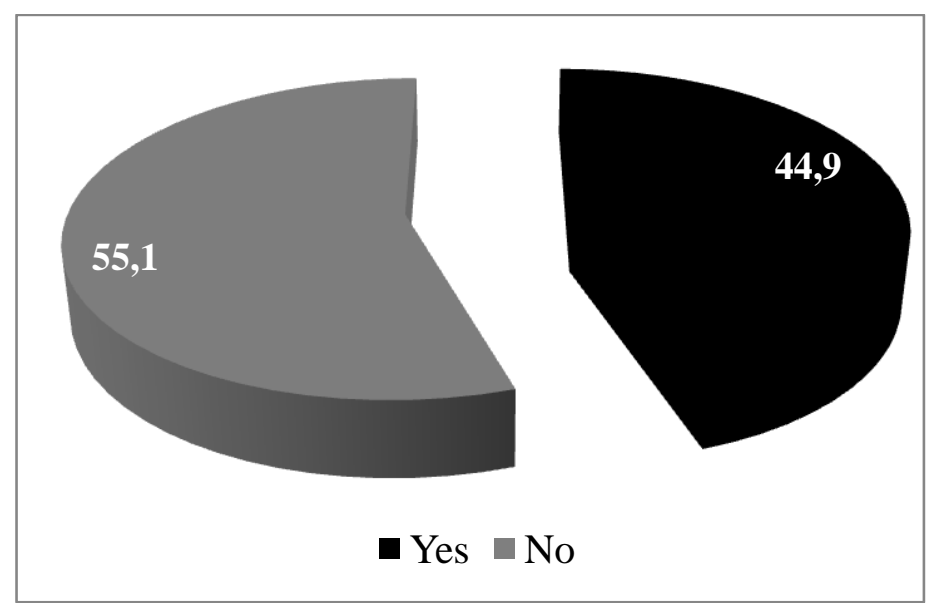

\section{Figure 3: Distribution of farmers with access to market information}

\subsection{Support services}

The provision of support services remain one of the major important interventions in the agricultural sector for rural development, commercialisation, food security, poverty alleviation and income generation of emerging farmers. The commercialisation of emerging farmers cannot be achieved without appropriate farmer support services. With adequate access to farmer support services, emerging agriculture can contribute to an increased agricultural growth, rural development and have a positive impact on the farm income. When the respondents were asked about support services various answers were given. The majority of the sampled farmers namely $64 \%$ claimed to be receiving support services for their farming enterprises (see Table 6) while $36 \%$ claimed not to be receiving any support service but had to rely on their own resources. When the farmers' were asked about extension services stated that the extension officer visited them once in a while. None of them could recall the visit routine.

When asked about their source of support services the farmers appeared to have more than one source of support and more than one type of support they were receiving. The majority of the farmers were receiving support from the government in the form of water, bales during droughts and medicine during disease outbreaks. Other farmers claimed that the department of agriculture assisted them with poultry structures and some farmers with piggery structures. The community NGO's were also assisting with market support. The NGO's were buying some of the farmers' commodity for feeding schemes and care homes. 
S.Afr. Tydskr. Landbouvoorl./S. Afr. J. Agric. Ext.,

Vol. 44, No. 1, 2016: $25-41$

DOI: http://dx.doi.org/10.17159/2413-3221/2016/v44n1a374

Table 6: Support services received by farmers

\begin{tabular}{|l|c|c|}
\hline \multicolumn{3}{|c|}{ Support received } \\
\hline & Count & Percentage \\
\hline Yes & 32 & 64 \\
\hline No & 18 & 36 \\
\hline
\end{tabular}

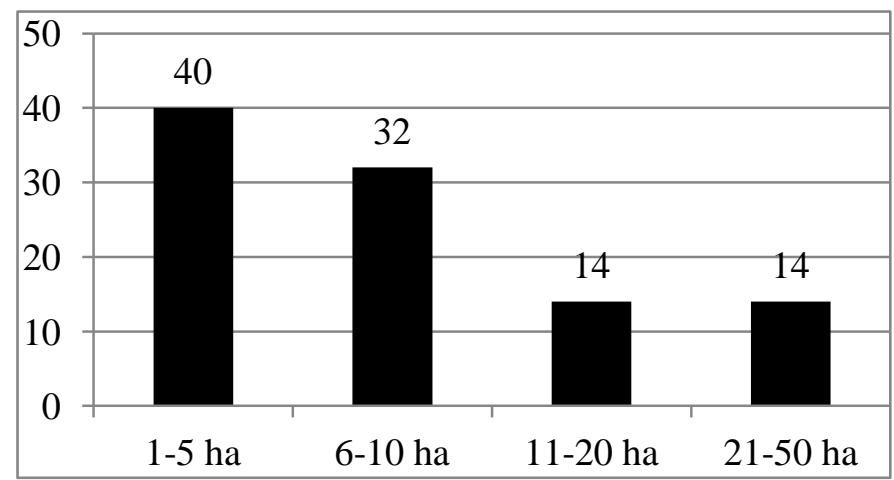

Figure 4: Land availability

The availability of land by the farmers seems to be also a concern in market participation. It is important that farmers have enough land to produce if they are to participate in commercial agricultural markets. The study found that $72 \%$ of the farmers are producing on land less than 10 hectares. Only $28 \%$ of the farmers are producing on land more than 10 hectares. This demonstrates that insufficient land availability in South Africa is still a challenge that many emerging farmers face. This has negative implications for sustainability and farm income, especially for livestock emerging farmers who depend on the availability of land for grazing and expansion of livestock production.

\section{CONCLUSIONS}

The emergent agricultural sector in South Africa has the potential to contribute to the growth of rural areas, and the reduction of unemployment, poverty and inequalities. The potential of emerging farmers to participate in this sector is untapped. Emerging farmers do not participate in markets that yield high returns. In order for emerging farmers to contribute to rural development and transit into the commercial farming sector the above mentioned aspects need to be addressed effectively. The main objective of the present study was to identify the challenges that prevent the commercialisation of emerging farmers into commercial agricultural markets. The study identified seven specific challenges to emerging farmers in the area. These were low education levels, lack of farming skills on crop and livestock production, poor management skills, high transportation cost, lack of market information, poor support services from the government, and participating in low remunerative marketing channels.

The majority of the produce produced by the farmers is sold to informal markets with low market value. Some of the farmers used more than one marketing channel. The distance to output markets is an important factor. Long distances to the market can be discouraging to 
S.Afr. Tydskr. Landbouvoorl./S. Afr. J. Agric. Ext.,

Vol. 44, No. 1, 2016: 25 - 41

DOI: http://dx.doi.org/10.17159/2413-3221/2016/v44n1a374
Khapayi \&

Celliers.

(Copyright)

farmers who want to commercialise. All the remunerative markets were located far away from the localities of the farmers. This implied that farmers had to travel long distances to formal markets on gravel road with their commodity loaded on poor transportation. Poor infrastructures and a lack of transportation infrastructure affect the quality of produce thus causing farmers' produce to be uneconomical or to lose quality.

The finding also showed that most respondents suffer from a lack of market information owing to a lack of communication, tools and support services from the government and extension officers. The majority of the farmers relied on word-of-mouth, family and selfresearch for information regarding market prices which in most cases was biased not accurate or up-to-date. Marketing information is very important for the market participation of emerging farmers. The availability of market information with regard to prices can boost the confidence of a farmer in marketing his or her produce. It can also help a farmer to choose marketing channels which ensure a better profit. The availability of market information helps farmers to make informed decisions about the marketing channels in which to participate. Farmers with no access to market information often make poor decisions. Market information helps the farmer by enhancing his or her bargaining power. The availability of market information about market variables such as prices and products in high supply and high demand in the market is important to the market performance of emerging farmers.

A business in general requires someone who is open-minded and has a quick understanding mind, skills such as record keeping and banking skills, labour management and the ability to choose a profitable enterprise and production method for that enterprise. Agricultural production methods in particular are dynamic and require someone who is current with developments and changes. All these requirements are achievable through education. When people are uneducated they become victims of being cheated and once people are cheated they refuse to adopt further innovation or change even if it is beneficial to them. Chemicals such as pesticides and herbicides and integrated pest management methods need someone who will understand them and their instructions because they can be dangerous to humans and produce resulting in loss of produce. However this does not mean that uneducated farmers or farmers with low education levels cannot be successful commercial farmers. The majority of the farmers in the present study were uneducated or had low education levels. This contributes to their lack of participation in formal markets.

Infrastructure such as roads, communication lines and farming facilities needed to be upgraded as it was restricting emerging farmers from commercialising to commercial farming. Fencing was required in the localities of the farmers. Irrigation equipment for crop farmers is important and needed for vegetable farming as water is a fundamental necessity. The unavailability of cultivation infrastructure such as cultivation tractors and ploughing implements was found to limit the farmers' productivity. The majority of the respondents claimed to be using the little money they have to hire these implements when needed. The implements of those who had them were old and poor in quality.

The farmers needed training in various production skills of which could boost their productivity and farm income. Skills such as training in the development of marketing strategies could help them access and secure marketing channels. Overcoming the challenges emerging farmers face can induce the farmers to move towards commercial agricultural systems. In order for emerging farmers to withstand both local and international competition, the South African government needs to consider support policies and regulation that are necessary to stimulate growth among emerging farmers. The State has a crucial role to play in 
S.Afr. Tydskr. Landbouvoorl./S. Afr. J. Agric. Ext.,

Vol. 44, No. 1, 2016: 25 - 41

DOI: http://dx.doi.org/10.17159/2413-3221/2016/v44n1a374
Khapayi \&

Celliers.

(Copyright)

increasing market participation of emerging farmers through encouraging group marketing, the upgrading of roads to enable smooth accessibility of farmers to output markets and the establishment of local point sales in farming rural areas. The government should enact laws and implement policies that are favourable to emerging farmers. Finally, the present study recommends that government provides planned workshops to all farmers in order to equip them with marketing knowledge.

\section{RECOMMENDATIONS}

Many limiting factors that affect the migration of emerging farmers into commercial agricultural farming throughout the Eastern Cape Province have been discussed in this paper. The main factors are low education levels among the farmers in order to understand the dynamics of agriculture, poor management, lack of farming skills, poor access to formal remunerative markets, high transportation costs to formal markets, poor market information and insufficient support services from the government. It was found that the government needs to take a leading role in investing in these support services. Access to productive land, production inputs, infrastructure, extension services, and value adding facilities in the location of the farmers, market information and transport logistics has been found to be the key factors influencing emerging farmers' participation in remunerative agricultural markets.

\section{ACKNOWLEDGEMENTS}

Financial assistance from the National Research Foundation and The Nelson Mandela Metropolitan University for this study is heartily acknowledged. The technical assistance of Distinguished Professor Mark Watson is highly appreciated.

\section{REFERENCES}

ALIBER, M., \& HALL, R. 2012. Support for smallholder farmers in South Africa: Challenges of scale and strategy. Development Southern Africa, 29(4), 548-562.

ANDREW, M., AINSLIE, A., \& SHACKLETON, C. 2003. Land use and livelihoods. Cape Town: Programme for Land and Agrarian Studies (PLAAS), University of the Western Cape.

ASSEFA, Y., CONLONG, D. E., VAN DEN BERG, J., \& MITCHELL, A. 2010. Distribution of sugarcane stem borers and their natural enemies in small-scale farmers' fields, adjacent margins and wetlands of Ethiopia. International Journal of Pest Management, 56(3), 233-241.

AYINKE, O. O. 2011. Contract farming in developing emerging farmers in South Africa: Exploring the Gledhow Mansomini sugarcane Scheme. Master's thesis. University of Stellenbosch.

BIENABE, E., \& VERMEULEN, H. 2011. Improving smallholders' market participation: Insights from a business scheme for maize in Limpopo Province, South Africa. Development Southern Africa, 28(4), 493-507.

CHIKAZUNGA, D. \& PARADZA, G. 2012. Can smallholder farmers find a home in South Africa's food-system? Lessons from Limpopo Province. The Institute for Poverty, Land and Agriculture Studies (PLAAS) Blog. http://www.plaas.org.za/blog/cansmallholderfarmers- find-home-South-Africa's-food-system-lessons-Limpopo province. Accessed 9 November 2012.

CRAIS, C. 2006. Custom and the politics of sovereignty in South Africa. Journal of Social History 39: 721-740. 
S.Afr. Tydskr. Landbouvoorl./S. Afr. J. Agric. Ext.,

Vol. 44, No. 1, 2016: 25 - 41

DOI: http://dx.doi.org/10.17159/2413-3221/2016/v44n1a374
Khapayi \&

Celliers.

(Copyright)

DEPARTMENT OF AGRICULTURE FORESTRY AND FISHERIES (DAFF). 2010. The Strategic Plan for South African Agriculture. Department of Agriculture, Directorate of Agricultural Information Services, Pretoria.

DEPARTMENT OF AGRICULTURE FORESTRY AND FISHERIES (DAFF). 2010. Integrated Growth and Development Plan 2011-2031. [Online] Available.

FREGUIN, S., ANSEEUW, W., \& D'HAESE, M. 2012. Demythifying contract farming: evidence from rural South Africa. Department of Agricultural Economics. Ghent University. Belgium.

HART, T., \& ALIBER, M. 2010. The need for an engendered approach to agricultural technology. Agenda, 24(84), 75-90.

HEINEMANN, E. 2002. The role and limitations of producer associations. European Forum for Rural Development Cooperation. Montpellier.

HUSSEY, J., \& HUSSEY, R. 1997. Business research. A practical guide for undergraduate and postgraduate students. Houndsmills: Macmillan.

KALIBWANI, F. 2005. Food security in southern Africa: current status, key policy processes and key players at regional level. New York: United Nations (UN).

KHAILE, P. M. E. 2012. Factors affecting technical efficiency of small-scale raisin producers in Eksteenskuil (Doctoral dissertation, University of the Free State Bloemfontein).

LODGE, T. 2005. Provincial government and state authority in South Africa. Journal of Southern African Studies 31: 737-753.

MACHETHE, C. L. 2004. Agriculture and poverty in South Africa: Can agriculture reduce poverty. Paper presented at the DBSA/HSRC/UNDP. Conference on overcoming underdevelopment in South Africa's second economy. Pretoria 28-29 October 2004.

MAKHURA, M. \& MOKOENA, M. 2003. Market access for small-scale farmers in South Africa. Pietermaritzburg: University of Natal Press.

MASON, J. 2002. Qualitative researching. Sage.

MOLOI, M. J., 2010. A comparison of socioeconomic characteristics that determine the farm income of emerging livestock and horticultural farmers in South Africa (Doctoral dissertation).

NATIONAL EMERGENT RED MEAT PRODUCERS ORGANISATION (NERPO) 2004. Marketing infrastructure development. [Online] Available at: [Accessed on $27 \mathrm{March}$ 2005] http://www.nerpo.org.za.

NATIONAL TREASURY 1996. Growth, Employment and Redistribution: A Macroeconomic Strategy. Department of Treasury.

NATIONAL TREASURY 2004. Land Affairs Vote 30; Estimates of National Expenditure 2003. Government Printers: Pretoria.

NATIONAL TREASURY 2005. Inter-governmental fiscal Review. National Treasury, Pretoria.

NATIONAL TREASURY (South Africa) \& Manuel, T. A., 2008. Budget Speech, 2008. National Treasury.

NATIONAL TREASURY (South Africa) \& Gordhan, P. 2010. Budget Speech, 2010. National Treasury.

NGEMNTU, S.T. 2010. Investigation of the production and marketing challenges faced by smallholder farmers in Amahlathi municipality a case study of Zanyokwe irrigation scheme and Silwindlala woman's project. MSc thesis. University of Fort Hare. Alice.

OLDFIELD, S. 2008. Participatory mechanisms and community politics: building consensus and conflict. Consolidating developmental local government: Lessons from the South African experience, 487-500. 
S.Afr. Tydskr. Landbouvoorl./S. Afr. J. Agric. Ext.,

Vol. 44, No. 1, 2016: 25 - 41

DOI: http://dx.doi.org/10.17159/2413-3221/2016/v44n1a374
Khapayi \&

Celliers.

(Copyright)

RALETING, P. M., 2011. An investigation of institutional factors influencing vegetable production amongst small-scale farmers in Central Eastern Cape: a case of six vegetable projects in the Nkonkobe Local Municipality. Doctoral dissertation. University of Fort Hare. Alice.

RANDELA, R. 2005. Integration of emerging cotton farmers into the commercial agricultural economy (Doctoral dissertation, University of the Free State Bloemfontein South Africa).

REARDON, T., \& BARRETT, C. B. 2000. Agroindustrialization, globalization, and international development: an overview of issues, patterns, and determinants. Agricultural economics, 23(3), 195-205.

SAUNDERS, J., FERNANDES, M. \& KOSNES, L., 2009. Retrieval-induced forgetting and mental imagery. Memory \& Cognition, 37(6), pp.819-828.

STATISTICS SOUTH AFRICA, 2010. Mid-year population estimates.

STATISTICS SOUTH AFRICA, 2012. Census 2011.

STATISTICS SOUTH AFRICA \& DEPARTMENT OF AGRICULTURE, 2000. Employment trends in agriculture in South Africa. Stats SA.

TROCHIM, W. M. 2006. Descriptive statistics. Research Measures Knowledge Base, 10-11.

TROCHIM, W. M. 2006. Qualitative measures. Research Measures Knowledge Base, 3619433.

VAN DEN BERG, J. 2013. Socio-economic factors affecting adoption of improved agricultural practices by small scale farmers in South Africa. African Journal of Agricultural Research, 8(35), 4490-4500.

VAN NIEKERK, P. du P. 2002. Product development as part of a positioning strategy for the hunting industry in the Eastern Cape, D-Tech. Thesis. Port Elizabeth: Port Elizabeth Technikon.

WYNNE, A. T. \& LYNE, M. C. 2003. An empirical analysis of factors affecting the growth of small-scale poultry enterprises in KwaZulu-Natal. Development Southern Africa, 20(5), pp.563-578.

WYNNE, A. T. \& LYNE, M. C. 2004. Rural economic growth linkages and small scale poultry production: A survey of producers in KwaZulu-Natal. Agrekon, 43(1), pp.1-21. 